УДК 378.017

DOI:

Наталія Педоренко, перший заступник директора КВНЗ “Бердичівський медичний коледж” ЖОР

\title{
МОДЕЛЬ ФОРМУВАННЯ КУЛЬТУРОЛОГІЧНОЇ КОМПЕТЕНТНОСТІ МАЙБУТНІХ МЕДИЧНИХ СЕСТЕР У ПРОЦЕСІ ФАХОВОЇ ПІДГОТОВКИ
}

У статті обтрунтовується поняття моделювання, процес дослідження складових формування культурологічної компетентності майбутніх медичних сестер у прочесі фахової підготовки, використовуючи метод моделювання. 3'ясовано, щь метою формування культурологічної компетенції майбутніх медичних сестер є формування культури особистості, професійно-медичної культури та розвитку професійно важливих особистісних якостей. Виокремлено иілььовий, змістовий, процесуальний, та критеріально-оцінний блоки. Розроблено модель готовності до формування культурологічної компетентності майбутніх медичних сестер у прочесі фахової підготовки.

Ключові слова: готовність до фахової діяльності; модель підготовки; процес моделювання; методи; форми; засоби; практичне впровадження моделі.

Puc. 1. Лim. 8.

Nataliya Pedorenko, First Deputy of Director Berdychiv Medical College

\section{MODEL OF FORMING OF CULTUROLOGICAL COMPETENCE OF FUTURE NURSES IN THE PROCESS OF PROFESSIONAL PREPARATION}

The article is grounded a design concept, a research process of constituents of forming of culturological competence of future nurses in the process of professional preparation, using a design method. It has been identified the main processes of forming of culturological competence of future nurses as a difficult multicomponent category, which all constituents are interdependent and reciprocal, and direct to organization of the process of forming of culturological competence of future nurses in the process of professional preparation on the basis of theoretical analysis and synthesis of the concepts such as "a design" and "a model".

It is marked, that the aim of forming of culturological competence of future nurses forms the nurse's personal culture, able to represent a high level of formed personality, professionally-medical culture, that is based on mastering of mental and ethical, communicative knowledge, abilities and skills, and also improvment and development of professionally important personality internals.

The successful and effective process of forming of culturological competence for its organization needs some of terms: plugging of future nurses in active creative activity, that stimulates cognitive interest in understanding of conformity to the aim of culture development as a process of creation, maintenance and translation of common to all mankind values; feeling of a person not only an object but also a subject of cultural and historical process; an orientation is in traditions, realities, customs, spiritual values of not only the community but also other nations; an ability expediently and effectively to come forward, to communicate in the modern world, operating by cultural concepts and offenses of different people.

During process of the of culturological competence forming of future nurses in the process of professional preparation we leaned against the traditional pedagogical principles of humanism and democracy, scientific character, unity of theory and practice, logical sequence of material presentation, professional orientation.

Traditional and unconventional methods, forms of studies are marked in this work. Among unconventional forms to realization of educational activity are used business games, disputes, problem situations, Delta plus, Case method.

Keywords: readiness for professional activity; model of preparation; design process; methods; forms; facilities; practical introduction of model.

П остановка проблеми. Багатоаспектного проникненняурізноманітнігалузі наукового пізнання педагогічних досліджень набуває метод моделювання для пояснення наукових понять, оскільки цей метод на сучасному етапі широко використовується в різноманітних галузях педагогічних досліджень. 3 метою дослідження складових формування культурогологічної компетентності майбутніх медичних сестер у процесі фахової підготовки, використовуючи метод моделювання, розроблено модель готовності формування культурогологічної компетентності майбутніх медичних сестер у процесі фахової підготовки.

У психолого-педагогічному словнику “модель" визначається як мисленна система, що імітує чи 


\section{МОДЕЛЬ ФОРМУВАННЯ КУЛЬТУРОЛОГІЧНОӤ КОМПЕТЕНТНОСТІ МАЙБУТНІХ МЕДИЧНИХ СЕСТЕР У ПРОЦЕСІФАХОВОӤ ПІДГОТОВКИ}

відображає певні властивості, ознаки, характеристики об’єкта дослідження або принципи його внутрішньої організації чи функціонування і презентується у вигляді культурної форми, притаманній певній соціокультурній практиці [7].

Модель, за В. Штоффом, це подумки уявлена або матеріально реалізована система, яка, відбиваючи або відтворюючи об'єкт дослідження, здатна його заміщати так, що іiі вивчення дасть нам нову інформацію про цей об'єкт $[8,19]$. Модель розглядається як знаряддя або форма пізнання. В залежності від форми Штофф ділив всі моделі на матеріальні та ідеальні $[8,23]$. Зокрема, до групи матеріальних моделей віднесені системи, побудовані на основі аналогії структури або поведінки моделі та об'єкту. Такі моделі названі математичними. Сюди включені аналогові, структурні, цифрові, а також кібернетичні моделі. Кібернетичні моделі побудовані на схожості поведінки та функцій зі складними системами.

Дослідник Г. Козлова вважає що моделлю $є$ створений із метою одержання і зберігання інформації спеціальний об'єкт, який відображає властивості, характеристики і зв'язки об'єкта оригіналу довільної природи, які є суттєвими для суб' єкту [4]. Науковець Ю. Лавриков стверджує, що модель готовності фахівця до професійної діяльності повинна схематично відображати процес набуття студентами професійних, специфічних, організаційно-управлінських i суспільних знань, необхідних компетентностей для здійснення професійної діяльності [5].

Відповідно до положень, розроблених В. Пікельная, моделювання може визначатись як: метод наукового дослідження; основа розробки нової теорії; механізм визначення перспективи розвитку [6, 248]. Свої розуміння поняття "моделювання" базуємо на визначенні І. Зязюна та Г. Сагач: “Дидактичне моделювання” - це система дій, яка забезпечую адекватне засвоєння (розуміння) модельованих властивостей, зв'язків і відношень пізнаваного і перетворюваного об'єкта (природного чи соціокультурного)" $[3,67]$. У розрізі досліджуваної проблеми під моделюванням розуміємо діяльність, у процесі якої створюється модель формування культурологічної компетенції майбутніх медичних сестер. На основі теоретичного аналізу і синтезу наведених понять “моделювання" і “модель" позначимо основи процесу формування культурологічної компетенції майбутніх медичних сестер, як складну багатокомпонентну категорію, всі складові якої взаємопов'язані та взаємообумовлені і спрямовані на організація процесуформування культурологічної компетенції майбугніх медичних сестер у процесі фахової підготовки.

Отже, на основі аналізу думок науковців, робимо висновок, що в результаті процесу моделювання повинна бути створена педагогічна модель, яка має володіти такими характеристиками: чітка мета і результат виконання моделі; відображені всі елементи об'єкта, які повинні бути в системному взаємозв'язку; змодельовані процеси, які будуть відбуватися; здатність до вдосконалення та змін.

Як засіб наукового пізнання моделі виконують три основні функції:

- описова функція моделі, яка полягає в систематизації емпіричних даних, точність, адекватність та повнота опису є вихідною передумовою для виконання будь-яких функцій;

- пояснювальна функція - полягає в розкритті зв'язків між встановленими в процесі описання фактами, залежностями та вже відомими законами, теоріями, гіпотезами;

- прогностична функція - спрямована на передбачення нових, не відомих раніш властивостей та відносин в об'єкті, що моделюється [1].

Метою формування культурологічної компетенції майбутніх медичних сестер, на наш погляд, формування культури особистості медичної сестри, здатної відображати високий рівень сформованості особистості, професійномедичної культури, що базується на засвоєнні морально-етичних, комунікативних знань, умінь і навичок, а також вдосконалені та розвитку професійно важливих особистісних якостей.

Для організації успішного й ефективного процесу формування культурологічної компетенції необхідна низка умов, які забезпечать досягнення поставленої мети. Під педагогічними умовами формування культурологічної компетенції майбутніх медичних сестер ми розуміємо сукупність чинників, що зумовлюють цей процес і забезпечують його успішний розвиток. До них відносимо: включення майбутньої медичної сестри в активну творчу діяльність, що стимулює пізнавальний інтерес до розуміння закономірності розвитку культури як процесу створення, збереження й трансляції загальнолюдських цінностей; відчугтя себе не лише об'єктом, а й суб'єктом культурноісторичного процесу; орієнтування в традиціях, реаліях, звичаях, духовних цінностях не тільки свого народу, але й інших націй; уміння доцільно й ефективно виступати, спілкуватися в сучасному світі, оперуючи культурними концептами й образами різних народів. 


\section{МОДЕЛЬ ФОРМУВАННЯ КУЛЬТУРОЛОГІЧНОЇ КОМПЕТЕНТНОСТІ МАЙБУТНІХ МЕДИЧНИХСЕСТЕР У ПРОЦЕСІФАХОВОӤ ПДГОТОВКИ}

Метою нашого дослідження є розкрити суть педагогічної моделі, відобразити ії основні елементи та взаємозв'язки між ними, ступінь їх організації й впливу один на одного. Тому, проаналізувавши науково-педагогічну літературу, нормативні документи медичних працівників, вважаємо, що необхідно дослідити практичні елементи організації процесу формування культурологічної компетентності майбутніх медичних сестер у процесі фахової підготовки, зокрема, розглянути принципи, методи, форми та засоби їх реалізації.

Виклад основного матеріалу. У процесі формування культурологічної компетентності майбутніх медичних сестер у процесі фахової підготовки ми опиралися на традиційні педагогічні принципи гуманізму й демократизму, науковості, єдності теорії і практики, логічної послідовності подання матеріалу, фахової спрямованості.

Принцип педагогічного гуманізму й демократизму. Навчальний процес повинен відбуватися на моральних принципах, в атмосфері взаєморозуміння та гуманності, але із тактовною вимогливістю викладача. Демократизм символізує самореалізацію студента й можливість досягнути максимального професіоналізму в процесі навчання.

Принцип науковості. Інформація, яку подає викладач передбачає розкриття причиновонаслідкових зв'язків явищ, процесів, подій, включення в засоби навчання науково перевірених знань, які відповідають сучасному рівню розвитку науки. Зміст навчального матеріалу має бути зафіксованим у навчальних програмах i підручниках і відповідати науковим твердженням і фактам та висвітлювати перспективи розвитку науки.

Принции єдності теорії з практикою. Засвоєні студентами теоретичні положення повинні закріплюватись та підтверджуватися практично, а результати практичної діяльності мають бути обгрунтовані теорією. У процесі підготовки майбутніх медичних сестер важливе місце займає практичне виконання засвоєних знань, які сприяють підвищенню рівня формування культурологічної компетентності у процесі фахової підготовки.

Принизип логічної послідовності подання матеріалу. Зміст навчального матеріалу повинен бути чітко структурований, послідовність викладання від простого до складного, від відомого до невідомого.

Принции фахової спрямованості грунтується на підпорядкуванні навчального процесу одній меті - формування культурологічної компетентності майбутніх медичних сестер у процесі фахової підготовки. Змісту навчальних дисциплін потрібно надати змістовну суть, завдяки котрій студенти набудуть необхідних компетентностей.

3 огляду на використання в навчальному процесі дисциплін культурологія, історія України, на яких вивчається уміння мобілізувати міжкультурні здібності під час професійної діяльності; уміння адекватно розпізнавати, осмислювати та оцінювати іншу лінгвокультуру, розуміти особливості представників іншомовної культурної спільноти в професійних ситуаціях; уміння прогнозувати можливі культурологічні перешкоди в умовах міжкультурного професійного спілкування і знаходити шляхи їх усунення; уміння мислити в порівняльному аспекті, розглядати свою країну в аспекті перетину культур і демонструвати культурну толерантність. Коротко розкриємо принципи навчання, покладені в структуру побудови педагогічної моделі.

Приниип зміни ролі викладача як носія інформації на керівника рольної діяльності. Завдяки використання інтерактивних технологій у процесі вивчення дисциплін культурологічного спрямування, викладач стає керівником діяльності студентів, він стежить за виконанням завдань, результати яких вони розміщають в системі, виправляє помилки, оцінює роботу та результати самостійного пошуку інформації. Завдяки цьому актуалізується діяльність та особистісно орієнтований підходи.

Приниип відкритості результатів навчальної діяльності студентів. Розміщений матеріал (звіти, доповіді, результати виконаних завдань, тести) у системі студентами ретельніше перевіряється, тому що він загальнодоступний і зростає персональна відповідальність за достовірність інформації.

Принциип розвитку індивідуальності cmудента. Під час навчання за допомогою інтерактивних технологій навчання відбувається постійна, активна взаємодія всіх учасників навчального процесу. Це співнавчання, взаємонавчання (колективне, групове, навчання у співпраці), де і студент і викладач $є$ рівноправними суб'єктами навчального процесу, розуміють, що вони роблять, рефлексують $з$ приводу того, що вони знають, вміють здійснювати. Безпосередньо, де дає змогу розкрити краще індивідуальні можливості кожного студента. Для кращого розкриття індивідуальності студента використовуються: мозковий штурм, мікрофон, коло ідей, робота в малих групах, займи позицію, прес-метод, акваріум, подорож рольові ігри та інші. 


\section{МОДЕЛЬ ФОРМУВАННЯ КУЛЬТУРОЛОГІЧНОӤ КОМПЕТЕНТНОСТІ МАЙБУТНІХ МЕДИЧНИХ СЕСТЕР У ПРОЦЕСІФАХОВОЇ ПІДГОТОВКИ}

Принцип гнучкості та адаптивності навчального середовищза. Навчальне середовище має адаптуватися до потреб студентів і забезпечувати реалізацію процесу навчання. Специфіка адаптивного навчання передбачає прищеплення особистості вміння гнучко реагувати на соціокультурні зміни у громадянському середовищі. Індивідуальні властивості особистості особливо рельєфно проявляються в майбутньому у стресових професійних ситуаціях, вирішення яких потребує розвиненої адаптивності й високої компетентності суб'єкта освітньо-професійної діяльності.

У процесі дослідження щодо формування культурологічної компетентності майбутніх медичних сестер у процесі фахової підготовки вважаємо, що для створення педагогічної моделі потрібно визначити методи, форми й засоби їі практичного впровадження.

Методи навчання $\epsilon$ одними 3 найважливіших компонентів освітнього процесу, без яких реалізувати навчальну мету та поставлені завдання практично неможливо. Завдяки методам студенти засвоюють зміст навчального матеріалу. Розглянемо освітні методи навчання, які, на нашу думку, доцільні в процесі формування культурологічної компетентності майбутніх медичних сестер у процесі фахової підготовки.

Під час навчання основним джерелом отримання теоретичних знань студентами $\epsilon$ метод навчальної лекції - це словесний метод, що припускає усний виклад матеріалу. На відміну від розповіді, лекція має складну структуру та складну логічну будову й займає весь час заняття. Не менш важливим за лекції $є$ наочний метод, що дає змогу візуально усвідомити факти які вивчаються. У нашому випадку засобами втілення цього методу є відео уроки, презентації, навчально-методичні посібники тощо. Варто відзначити, що “засіб навчання” - це матеріальний або ідеальний об'єкт, який використовується для засвоєння знань студентами, формування досвіду пізнавальної й практичної діяльності. Засіб навчання суттєво впливає на якість знань, їх розумовий розвиток і професійне становлення [2].

Для виконання практичних завдань використано репродуктивно-творчі методи. Студенти відтворюючи дії, відображені у презентації, описані в навчально-методичному посібнику, задля активного засвоєння та запам'ятовування інформації, виконуючи завдання за зразком, здійснюють репродуктивно-творчу діяльність, що $є$ особливо ефективним для відпрацювання практичних умінь і навичок.

Завершальний етап навчання - оцінювання рівня знань студентів. Щоб здійснити оцінку навчальної діяльності студентів, використано методи інтерактивного навчання. Методи усного контролю використовували у вигляді тестів, експрес-опитування, контрольна вправа, або творче завдання, порт фоліо.

Для забезпечення реалізації зазначених методів навчання визначено форми їх здійснення. У процесі формування культурологічної компетентності майбутніх медичних сестер у процесі фахової підготовки використано такі традиційні форми як лекції, практичні й лабораторні заняття, факультативні заняття, консультації, індивідуальні заняття, самоспину роботу, наукові конференції тощо. Серед нетрадиційних форм реалізації навчальної діяльності використано ділові ігри, диспути, проблемні ситуації, “Дельта плюс”, метод-кейсів.

Для формування культурологічної компетентності майбутніх медичних сестер у процесі фахової підготовки потрібно знати способи реалізації обраних методів і форм. Серед сучасних традиційних засобів було використано підручники навчально-методичні посібники, друковані матеріали, комп'ютерну техніку, Інтернеттехнології, прикладне програмне забезпечення. Оскільки завданням нашого дослідження $є$ формування культурологічної компетентності майбутніх медичних сестер у процесі фахової підготовки, ми використали такі засоби навчання як: графічні (картини, малюнки), технічні (діафільми, звуко-і відеозаписи), індивідуалізації навчального процесу, електронного контролю знань, оцінювання результатів діяльності за системою накопичення балів.

Вважаємо, що поєднання традиційних і нетрадиційних засобів навчання сприяє формуванню сучасного фахівця 3 грунтовними знаннями та необхідними для фахової діяльності компетентностями. На основі проведеного аналізу визначено складові елементи педагогічної моделі формування культурологічної компетентності майбутніх медичних сестер, яка спрямована на формування умайбутнього фахівця які не тільки володіння спеціальними знаннями у своїй галузі на високому рівні, але й були б носіями та прикладом високої загальної та професійномедичної культури. Метою розробленої педагогічної моделі $є$ виразити педагогічний процес поетапної підготовки фахівців, формування культурологічної компетентності майбутніх медичних сестер у процесі фахової підготовки (рис. 1).

Розроблена педагогічна модель готова до впровадження в навчальний процес. У подальших 
МОДЕЛЬ ФОРМУВАННЯ КУЛЬТУРОЛОГІЧНОЇ КОМПЕТЕНТНОСТІ МАЙБУТНІХ МЕДИЧНИХ СЕСТЕРУ ПРОЦЕСІ ФАХОВОЇ ПІДГОТОВКИ

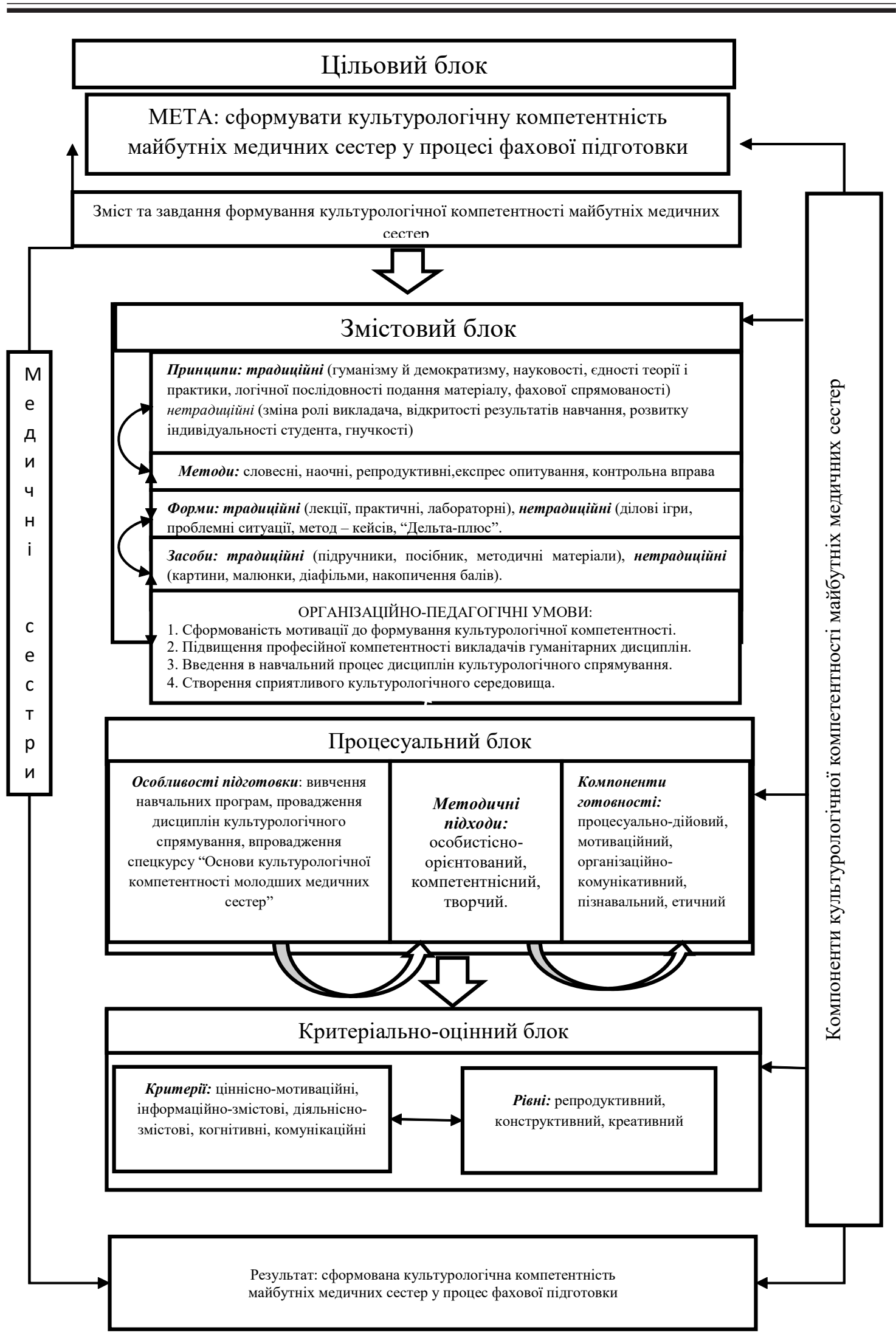

Рис. 1. Модель формування культурологічної компетентності майбутніх медичних сестер 
дослідженнях необхідно здійснити перевірку ефективності запропонованої моделі формування культурологічної компетентності майбутніх медичних сестер у процесі фахової підготовки, застосувавши виділені організаційно-педагогічні умови, методику організації процесу підготовки студентів. У процесі здійснення такої перевірки педагогічна технологія розглядатиметься як послідовна низка вказівок і операцій моделювання, реалізації, діагностики ефективності корекції процесу фахової підготовки майбутніх медичних сестер на основі культурологічної компетенції.

\section{ЛІТЕРАТУРА}

1. Горбатюк, Р. М. Теоретико-методичні засади професійної підготовки майбутніх інженерів-педагогів комп'ютерного профілю: автореф. дис. на здобуття наук, ступеня доктора пед. наук: спец. 13.00.04 “Теорія і методика професійної освіти” / Р. М. Горбатюк. - Тернопіль, 2011. - 46 c.

2. Зайченко, I. В. Педагогіка: навч. посіб. / I. В. Зайченко - 2-ге вид. - К., Освіта України, KHT, 2008. - 528 c.

3. Зязюн I. А., Сагач Г. М. Краса педагогічної дії: навч. пос. для вчителів, аспірантів, студентів середніх та вищих навч. закладів / І. А. Зязюн, Г.М. Сагач - К.: Укр-фін. інститут менеджменту і бізнесу, 1997. - 302 с.

4. Козлова, Г. М. За технологіями активного навчання / Г. М. Козлова - К.: Вища освіта України. - 2002. - № 2. - С. 42-15.

5. Лавриков, Ю. А. Модели профессиональной подготовки экономиста./ Ю.А. Лавриков - Львів. - 1973.- $119 \mathrm{c}$.

6. Пикельная В. С. Теория и методика моделирования управленческой деятельности: дис. докт. пед. наук: 13.00.01 / Пикельная Валерия Семеновна. - Киев, 1993. - 374 с
7. Психолого-педагогический словарь. Ростов-на-Дону, 1998. - 256 с.

8. Штофф В.А. Моделирование и философия / В.А. Штофф. - Ленинград: Наука, 1966. - 302 с.

\section{REFERENCES}

1. Horbatiuk, R. M. (2011). Teoretyko-metodychni zasady profesiinoi pidhotovky maibutnikh inzhenerivpedahohiv kompiuternoho profiliu [The theoretical and methodical principles of professional training of future engineers-teachers of a computer profile]. Extended abstract of Doctor's thesis. Ternopil, 46 p. [in Ukrainian].

2. Zaichenko, I. V. (2008). Pedahohik: navch. posib. [Pedagogy: Teaching manual]. Kyiv: Osvita Ukrainy, KNT, 528 p. [in Ukrainian].

3. Ziaziun, I. A., \& Sahach, H. M. (1997). Krasa pedahohichnoi dii: navch. pos. dlia vchyteliv, aspirantiv, studentiv serednikh ta vyshchykh navch. zakladiv [The beauty of pedagogical action: teaching manual for teachers, post-graduate students, and the students of secondary and higher education establishments]. Kyiv, 302 p. [in Ukrainian].

4. Kozlova, H. M. (2002). Za tekhnolohiiamy aktyvnoho navchannia [In accordance with the active studying technologies]. Kyiv: Vyshcha osvita Ukrainy, pp. 42-15. [in Ukrainian].

5. Lavrykov, Yu. A. (1973). Modely professyonalnoi podhotovky ekonomysta [The models of vocational training of economist]. Lviv, 119 p. [in Russian].

6. Pykelnaia, V. S. (1993). Teoriya i metodika modelirovaniya upravlencheskoy deyatelnosti [The theory and methods of management activity]. Doctor's thesis. Kyiv, $374 \mathrm{p}$.

7. Psikhologo-pedagogicheskiy slovar (1998). [Psychological and pedagogical dictionary]. Rostovna-Donu, 256 p. [in Russian].

8. Shtoff, V. A. (1996). Modelirovanie i filosofiya [Modeling and philosophy]. Lenynhrad: Nauka. 302 p. [in Russian].

Стаття надійшла до редакції 27.12.2018

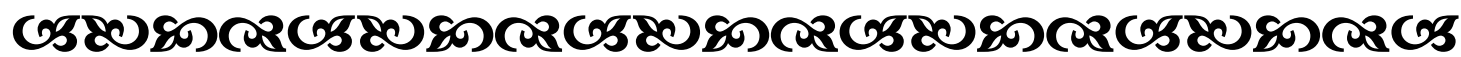

"Ефективність навчання, його гуманістична сутність зумовлюються в першучергу пробесіоналізмом і висоқою технологічною қультурою педагога".

$$
\begin{array}{r}
\text { Василь Сухомлинський } \\
\text { уқрайнський педагог, публіиист }
\end{array}
$$

"ТТільки самоосвіта спроможна сбормувати справді ерудовану та всебічно розвинену особистість".

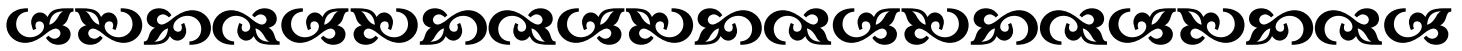

